\title{
Internal structure and seismic facies of the deep-water sediment drifts off northern Graham Land, Antarctic Peninsula: results from a very high-resolution survey
}

\author{
M. Canals, ${ }^{1 *}$ R. Urgeles,${ }^{1 *}$ F. Estrada, ${ }^{2 *}$ GEBRAP 96/97 Team ${ }^{\dagger}$ \\ ${ }^{1}$ Universitat de Barcelona, Dept. Estatigrafia i Paleontologia, E-08071 Barcelona, Spain \\ ${ }^{2}$ Institut de Ciències del Mar, Dept. Geologia Marina i Oceanografia Física, E-08039 Barcelona, Spain
}

\begin{abstract}
High-resolution Bottom Parametric Source profiles have revealed details of the sedimentary structure of the upper $150 \mathrm{~ms}$ of the sediment drifts off the Pacific margin of Graham Land, Antarctic Peninsula. These profiles show that the dominant process is hemipelagic sedimentation, although instability processes are also important, as shown by the widespread presence of transparent, chaotic and semi-transparent acoustic facies. These new data are relevant to the evaluation of the palaeoenvironmental potential of the sediment drifts and show that the amount of remobilised sediment is significant in some of the drifts.
\end{abstract}

\section{INTRODUCTION}

On the Pacific margin of Graham Land, Antarctic Peninsula, a large variety of tectonic and depositional environments are present. The present-day margin structure is the result of the progressive collision from southwest $(45-50 \mathrm{Ma})$ to northeast (3-5 Ma) of the Antarctic-Phoenix ridge with a trench at the margin (Larter and Barker, 1991). However, the post-subduction history of the outer shelf resembles that of a young passive margin (Larter and Barker, 1991). Progradation of the shelf edge is generally focused into lobate extensions opposite the mouths of broad glacial troughs (Larter and Cunningham, 1993; Pudsey and others, 1994). Seismic correlation with continental rise sediments overlying young oceanic crust in the younger collision zones suggests that the prograding sequences there have formed since 6 Ma (Larter and Barker, 1989, 1991).

On the Pacific continental rise off Graham Land, longrange side-scan sonar (GLORIA) data showed a complex pattern of channels (Tomlinson and others, 1992). Multichannel seismic (MCS) reflection profiles also showed eight very large sediment mounds developed between the channel systems. According to Rebesco and others (1996), the sediment mounds are typically asymmetric in cross-section, and the gentler flanks are underlain by sediments which show fine acoustic stratification, with planar, parallel or subparallel, laterally continuous reflectors conformable to the sea floor.

The sediment mounds have been interpreted as sediment drifts (McGinnis and Hayes, 1995; Rebesco and others, 1996) which would have a largely terrigenous (non-

\footnotetext{
* UA Geociències Marines CSIC-UB.

† The GEBRAP 96/97 team: A. M. Calafat, J. Sorribas, B. Alibès, I. Cacho, J. L. Casamor, J. Fabrès, M. J. Prieto, M. A. Rodríguez, M. Farran, F. Ramil, M. A. O. De Batist, T. van Cauwenberghe, J. Prades, P. Jornet, C. Mir, R. Forcada.
}

biogenic, hemipelagic) composition, containing a high-resolution expanded record of the Antarctic Peninsula glacial history. They have been formed in three stages (McGinnis and Hayes, 1995; Rebesco and others, 1996): (1) pre-drift stage, in which mainly terrigenous material is transported downslope by turbidity currents; (2) drift growth, in which southwest-flowing thermohaline bottom currents entrained the fine-grained component of turbidity flows derived from the continental slope; (3) drift maintenance, in which the sediment mounds continue to be fed by the fine-grained components of turbidity currents travelling along the channels that drain the continental slope, but the influence of bottom currents on sediment distribution is reduced.

\section{METHODS}

A very high-resolution, systematic survey of the sediment drifts $\left(64-67^{\circ} \mathrm{W}, 62.30-65^{\circ} \mathrm{S}\right)$ has been carried out using the hull-mounted Bottom Parametric Source (BPS) system on board the Spanish R/V Hespérides. The data consist of $3180 \mathrm{~km}$ of mainly northeast-southwest oriented profiles (Fig. 1). The operating frequency of the BPS is in the range $4-2 \mathrm{kHz}$, and during the cruise a maximum penetration of $150 \mathrm{~ms}$ was achieved. The system was operated at 10 knots $\left(18.5 \mathrm{~km} \mathrm{~h}^{-1}\right)$ and triggered in multipulse mode at a frequency of $1-3 \mathrm{~s}$, in water depths of $2500-4000 \mathrm{~m}$. This resulted in a horizontal resolution of about $5 \mathrm{~m}$, while the vertical resolution was better than $1 \mathrm{~m}$. Acoustic facies interpretation was made according to the classification by Damuth (1980).

\section{RESULTS}

At the base of the slope of the Graham Land margin, the BPS records show five sedimentary mounds that correspond to the area of the four northernmost ones identified by Rebesco and others (1996). These are bounded by channels whose floors range from flat to $\mathrm{V}$-shaped.

Three types of morphologies can be recognised in the 


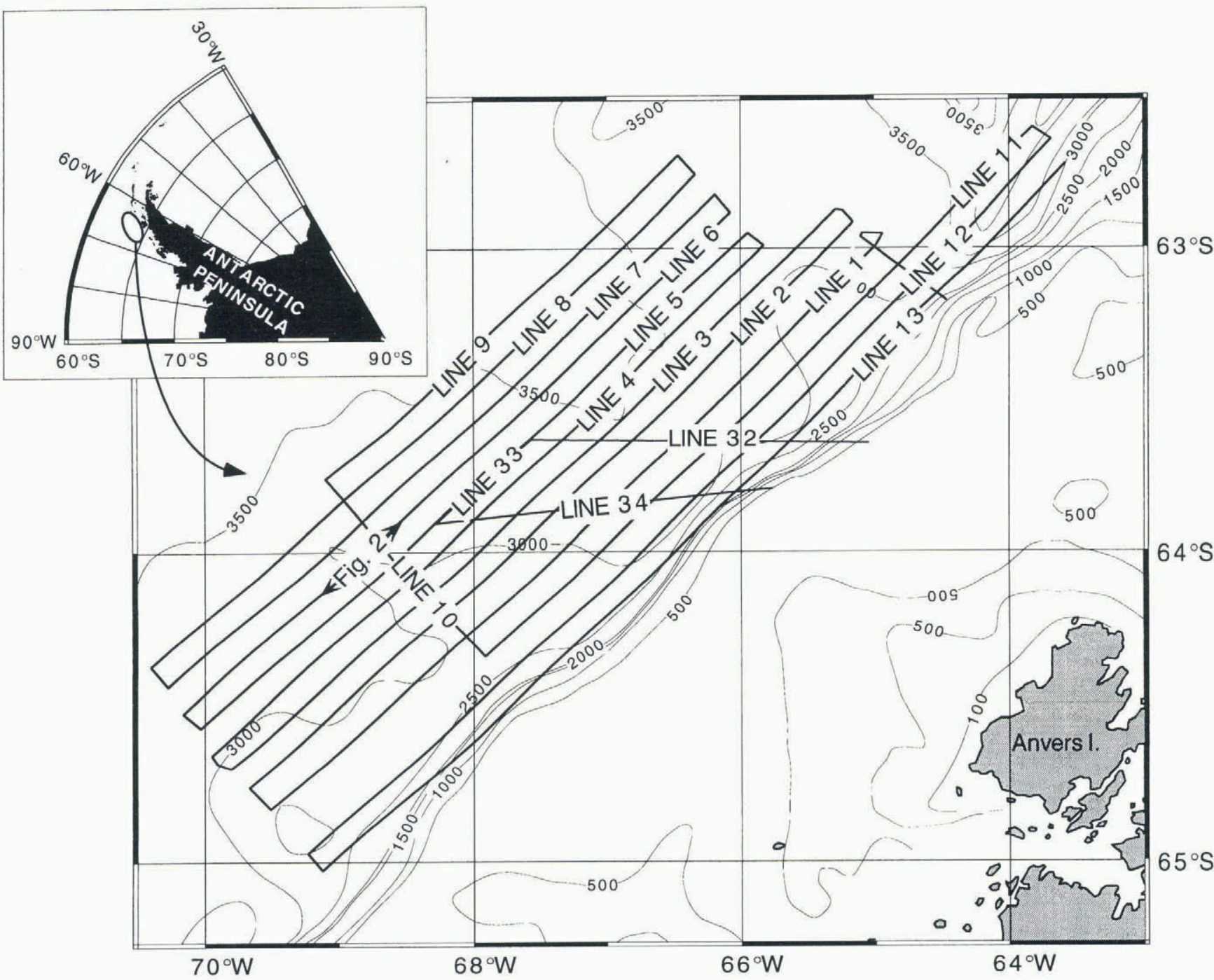

Fig. 1. Location of the study area and profile illustrated in Figure 2. Interval for the bathymetric contours is $500 \mathrm{~m}$. Bathymetric contours are from a preliminary map by the SEDANO working group.

sediment mounds: symmetric and strongly asymmetric with the steeper side facing northeast or southwest (Fig. 2). The crests of the drifts are $500 \mathrm{~m}$ to $1 \mathrm{~km}$ above the nearest channel axis. These channels are incised $80-170 \mathrm{~m}$ with respect to the surrounding uneroded sea floor. Thus, we consider that the sediment mounds have been only slightly modified by incision of the channels. In BPS records the seismic facies of the sediment mounds are mainly parallel-stratified. Chaotic, transparent and semi-transparent facies appear interbedded within the stratified ones or form lenticular morphologies (Fig. 2). In the channel thalwegs chaotic and semi-transparent facies appear, while divergent-stratified and sigmoidal are locally present in the channel margins, forming levee-like deposits.

The BPS profiles show that the dominant process in the study area is hemipelagic sedimentation, as this process is commonly associated with uniform parallel-stratified facies. However, instability processes are important within the sediment mounds covered by this survey. Evidence of instability is provided by the chaotic, transparent and semi-transparent facies, which we interpret as having been generated by the different degrees of disintegration of the original sediment mass. The thickness of the individual deposits related to instability is highly variable, and ranges from a few $\mathrm{ms}$ to a maximum of $40 \mathrm{~ms}$. Laterally such deposits can extend up to $100 \mathrm{~km}$, and individual events can reach $150 \mathrm{~km}^{3}$.

Scars on top of the sediment mounds and on their flanks can also be observed truncating the stratified facies. This evidence suggests that instability processes originate near the crests of the sediment mounds, although other sources, such as the channel margins, have also been identified.

Several bodies corresponding to single-event instabilities can be observed in the BPS profiles. These bodies can be grouped in six main levels that appear to correlate well between the different mounds, probably indicating that such processes are cyclic and driven by regional factors. Gravity cores taken in the study area have shown that the upper $6 \mathrm{~m} \mathrm{(about} 8 \mathrm{~ms}$ ) correspond to the transition between the Last Glacial and the present-day interglacial (Camerlenghi and others, 1997). Thus our data probably represent several glacial-interglacial cycles, and each of the different levels at which instability-related deposits have been observed may correspond to a different cycle.

\section{DISGUSSION AND CONCLUSIONS}

The overall system of mounds and channels seems to be stable and, within the interval represented on our BPS profiles, the channels have not migrated, allowing a relatively stable sediment-mound morphology to be maintained. However, how this morphology is affected by the channels and to what extent the sediment mounds control the channels pathway, are still unresolved questions. 


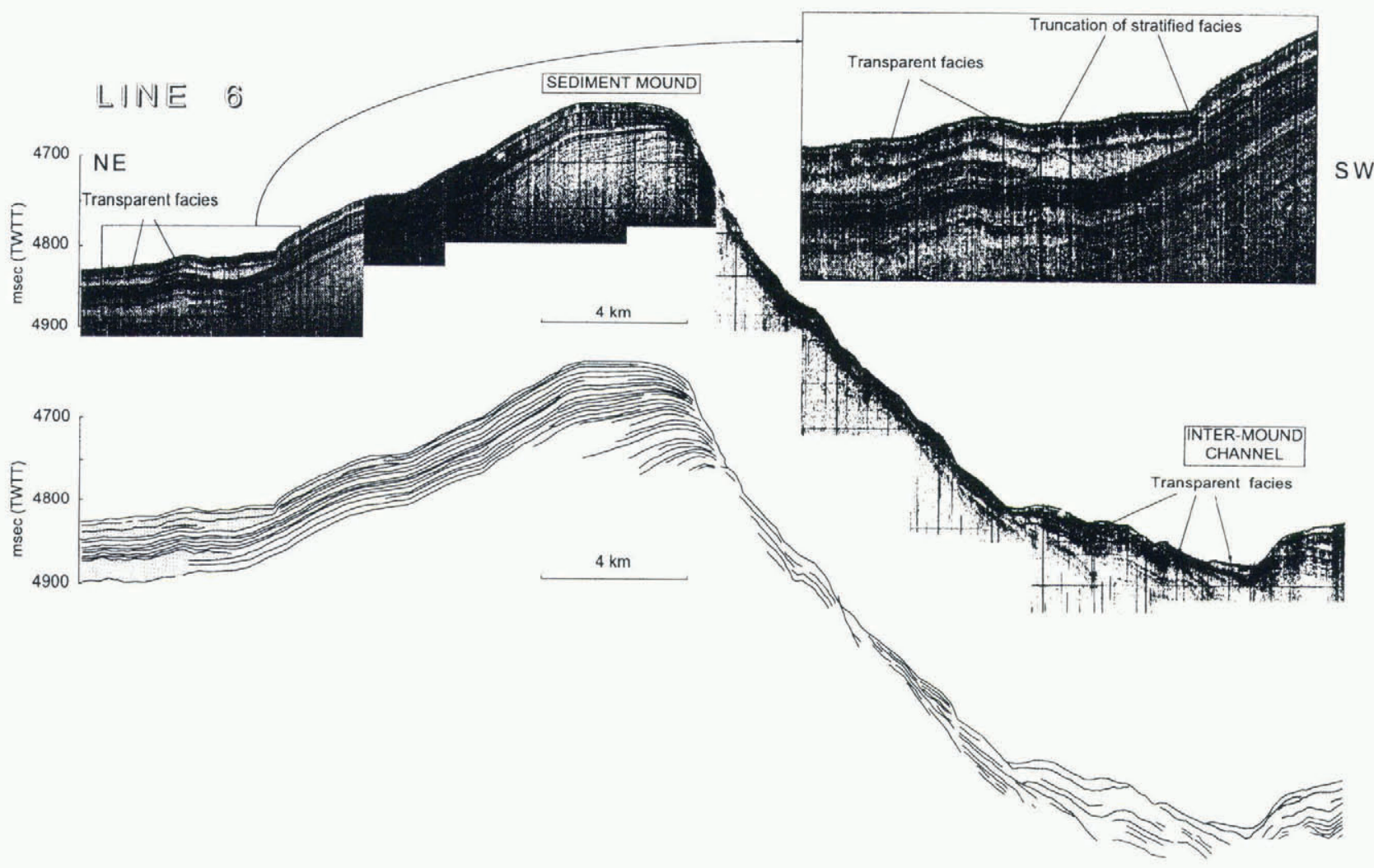

Fig. 2. High-resolution BPS profile and interpretation, showing one of the sediment mounds (mound 3 of Rebesco and others, 1996). Note the presence of transparent facies, interpreted as debris flows, on the northeastern flank and in the channel to the southwest. Note also the presence of slumps on the southwestern flank of the sediment mound.

From our BPS data we infer that in recent times (150-0 $\mathrm{ms}$ ) bottom currents have not played an important role in shaping the sediment mounds. Only in the most distal part and in the uppermost part of one of the sediment mounds does the configuration of the reflectors allow us to infer slight bottom-current interaction. Hence, hemipelagic sedimentation should have draped and preserved the mound morphology formed during the drift-growth stage.

After hemipelagic sedimentation, mass-wasting seems to be the second most important process taking place on the sediment mounds. Thus, from evaluation of our BPS data, we consider that the palaeoenvironmental potential of the four northernmost sediment drifts along the continental rise off Graham Land is not as great as has previously been suggested (Rebesco and others, 1996), since large amounts of remobilised material exist.

Various triggering mechanisms able to generate the different mass-wasting events can be invoked in terms of the cyclic pattern and widespread distribution of transparent masses: (1) sediment pore-pressure fall and rise coinciding with changes of sea level; (2) periods of high sediment input coinciding with advance of grounding ice and sealevel fall (reinforced by item 1); (3) earthquakes.

\section{ACKNOWLEDGEMENTS}

This work was supported by the project ANT95-0889-C0201, funded by the Spanish National Agency for Science and Technology (CICYT), and the Comissionat per a Universitats i Recerca (CUR) of the Generalitat de Catalunya project GRQ94-1026. R. Urgeles held a Fellowship of the CUR. We would particularly like to thank the master and crew of the R/V Hespérides for their efficiency and coopera- tion at sea. Constructive reviews from R. D. Larter and L. De Santis are also acknowledged.

\section{REFERENCES}

Camerlenghi, A., M. Rebesco and C. J. Pudsey. 1997. High resolution terrigenous sedimentary record of the sediment drifts on the Antarctic Peninsula Pacific margin (initial results of the "SEDANO" program). In Ricci, C.A., ed. The Antarctic region: geological evolution and processes. Siena, Terra Antarctica, 705-710.

Damuth, J. E. 1980. Use of high frequency $(3.5-12 \mathrm{kHz})$ echograms in the study of near bottom sedimentation processes in the deep sea: a review. Mar. Geol., 38, 51-76.

Larter, R. D. and P. F. Barker. 1989. Seismic stratigraphy of the Antarctic Peninsula Pacific margin: a record of Pliocene-Pleistocene ice volume and paleoclimate. Geology, 17 (8), 731-734.

Larter, R. D. and P. F. Barker. 1991. Neogene interaction of tectonic and glacial processes at the Pacific margin of the Antarctic Peninsula. In Macdonald, D.I.M., ed. Sedimentation, tectonics, and eustasy: sea level changes at active margins. Oxford, Blackwell Scientific. International Association of Sedimentologists, 165-186. (IAS Special Publication 12.)

Larter, R. D. and A. P. Cunningham. 1993. The depositional pattern and distribution of glacial-interglacial sequences on the Antarctic Peninsula Pacific margin. Mar. Geol., 109, 203-219.

McGinnis, J. P. and D. E. Hayes. 1995. The roles of downslope and alongslope depositional process: southern Antarctic Peninsula continental rise. In Cooper, A. K., P. F. Barker and G. Brancolini, eds. Geology and seismic stratigraphy of the Antarctic margin 1. Washington, DC, American Geophysical Union, 141-156. (Antarctic Research Series 68.)

Pudsey, C. J., P. F. Barker and R. D. Larter. 1994. Ice sheet retreat from the Antarctic Peninsula shelf. Continental Shelf Res., 14(15), 1647-1675.

Rebesco, M., R. D. Larter, A. Camerlenghi and P. F. Barker. 1996. Giant sediment drifts on the continental rise west of the Antarctic Peninsula. Geo, -Mar. Lett., 16, 65-75.

Tomlinson, J. S., C. J. Pudsey, R. A. Livermore, R. D. Larter and P. F. Barker. 1992. Long-range side scan sonar (GLORIA) survey of the Antarctic Peninsula Pacific margin. In Yoshida, Y., K. Kaminuma and K. Shiraishi, eds. Recent progress in Antarctic earth science. Tokyo, Terra Scientific Publishing Co., 423-429. 